\title{
Environmental Awareness Character Study of Kuala Langsa Society
}

\author{
Siska Rita Mahyuny a, *, Ekariana S. Pandia ${ }^{\text {b }}$, Vita Ria Mustikasari ${ }^{\text {c }}$, Rizal Nasution ${ }^{\text {d }}$ \\ ${ }_{a, b, c, d}$ Study epartment of Biology Education, Universitas Samudra \\ Langsa, 24416, Indonesia
}

*Corresponding author's e-mail: mahyunika@unsam.ac.id

\begin{abstract}
Mangrove Forest, located in Kuala Langsa, Aceh Province of Indonesia, is one of the local, regional, national, and international ecotourism destinations. However, there are some issues about the awareness character of the society around Kuala Langsa. This research purpose is to have a better understanding of the people and their knowledge concerning to environmental issues. The technique used in the research was a random sampling interview combined with customized questionnaires as an indicator of understanding about environmental issues awareness taken from 100 respondents. The data value shown by Likert scale as follow: $46.8 \%$ littering habits, $33 \%$ toilet sanitation, $36.2 \%$ reuse of product. The research concludes the awareness character of Kuala Langsa society influenced by the educational level, economic condition, and their opportunity to gain access to the next level of educational grade, and also low frequency of government appeal to the society of how important to always maintain and preserve the Kuala Langsa Mangrove.
\end{abstract}

\section{Introduction}

Environmental awareness is an act or effort conduct by a person or society to prevent environmental destruction around, also to improve and maintain the quality of the environment until the benefit and goodness feel continuously[4]. National economic and social survey of 2014 data describe the indicator behavior of environmental awareness character such as: water maintainance, waste management, and the care for environment[10]. Even though $71 \%$ of this planet is water, only $2.5 \%$ of it is plain water, while the rest contains high salinity. And only $1 \%$ of that $2.5 \%$ could be utilized by a human directly or approximately about $30 \%$ of total plain water supply. Based on that condition pushes us to manage and utilize the water efficiently and wisely. 
Puti and Safuridar research explain[8] that Mangrove forest of Kuala Langsa plays an important role to educate society nearby to be aware and preserve the biodiversity inside the mangrove forest. Vast population growth also had a significant effect to the uncontrolled environmental problem, but the society commitment determine the goverment act to protect the site since it also the economical resource for the society nearby. It is possible to build and develop a society with environmental awareness through education and school. School as an educational institution plays an important role to thought the student about human behavior and their effect on the environment and earth sustainably[5].

Formal education only such as a school is not enough, because the society outside the school contributes the most to the environmental problems and other issues related. Therefore, certain educational pattern outside the school is urgently required by society to gain the environmental awareness character.

Vast population growth, followed by their activity produces a high amount of waste too. Therefore, this waste enhancement must be balanced with the good and sustainable waste management. Begin with the household, since it is the main waste producer on human history. Therefore, a pro-environmental society is needed to reduce the waste volume or to recycle it.

Environmental awareness showed by the household chariness on the sanitation around. This behavior also referred on the experience of the households to judge the condition or the quality of the neighborhood and their effort when a distraction or any environmental pollution occurs [3].

Gampong Kuala Langsa is located on the West Langsa sub-district and one of the littoral territories of Langsa City. The area holds the mangrove forest as their resource which was later developed as an ecotourism site. The width is \pm 8.000 ha[2]. But ironically, the view of the neighborhood around is still far from the ecotourism principal: Ecologically sustainable, which means that all of the environmental function - biologically, physically, and also socially goes well.

The situation caused by direct wasting by households (fluid or solid) downward houses which is tidal area of the sea. Many local still believes that the high tide would sweep and brought about the waste to the bottom of the sea [9]. Therefore, how important it is to have a complete understanding about the society paradigm about sanitation issues and other problem-related in Kuala Langsa as a basic knowledge to start the environmental awareness character education and fix their mindset about the environment and also to the neighborhood around, to conscious them of how precious their Kuala Langsa about. The data gained also useful to set and/or apply any social policy forward to the neighborhood. The research goal is to have a comprehensive description about environmental awareness character of Kuala Langsa society - the site of conservation and ecotourism. 


\section{Method}

The reserach design is qualitative method on the research object. The method used in this research is descriptive-qualitative with primer and secondary data gained by interviewing on guidelines, observation, and documentation using a qualitative approach. The research aim is to identify the environmental character of Kuala Langsa Society based on Likert scale.

a. Population and Sample of Research

The population sample used in this research was the society of Kuala Langsa. Samples were respondents as part of and representing the whole population of Kuala Langsa society. The population live in the nearest radius to the ecotourism site. The 100 samples were taken by random sampling.

b. Data Collection

The data collection instruments in this research followed by stages such as observation, interview, and questionnaire:

- Observation

The data observation taken from the people of Kuala Langsa, West Langsa sub-district, Langsa City, in Aceh Province

- Interview The interview taken from 100 respondent from the population of Kuala Langsa society.

- Questionnaire

The questionnaire data contain parameters such as littering habits, home toilet, waste product re-use, and environment water quality (condition). The questionnaire was filled directly by the respondents or filled by the interviewer.

c. Data Analysis

The data analysis technique was carried out into: data reduction, data exposure, and inference[11]. The data analysis technique used in this research was the Likert scale to count respondents answer index with the formula as followed:

Index Value $=((\mathrm{F} 1 \times 1)+(\mathrm{F} 2 \times 2)+(\mathrm{F} 3 \times 3)+(\mathrm{F} 4 \times 4)+(\mathrm{F} 5 \times 5) / 4)$

Index Values gained were interpreted into: 
Table 1.

Index Values gained interpret

\begin{tabular}{ccl}
\hline No & Interval & \multicolumn{1}{c}{ Information } \\
\hline 1 & $0 \%-19.99 \%$ & Very Poor/Very Low/Never \\
2 & $20 \%-39.99 \%$ & Not Good/Low/Rarely \\
3 & $40 \%-59.99 \%$ & Normal/Sufficient/Sometimes \\
4 & $60 \%-79.99 \%$ & Good/High/Often \\
5 & $80 \%-100 \%$ & Fine/Fantastic \\
\hline
\end{tabular}

\section{Results}

From a hundred respondents, their profession showed by figure 1. (a). $44 \%$ of housewife activities are peeling the oyster given by their families or other member of the society as their side job, $35 \%$ work as a fisherman, while $9 \%$ of the respondents was a student, and the rest of them had a various profession, such as enterpreneur, labourer, and also unemployement (small percentage).On the interview discussion, generally the population nearby talk most about the economic topics and has less information and knowledge about environmental awareness character, sanitation, quality improvement and conservation, specially around the mangrove forest. The reserach show that education level inline with economic growth and human resources development index[6].

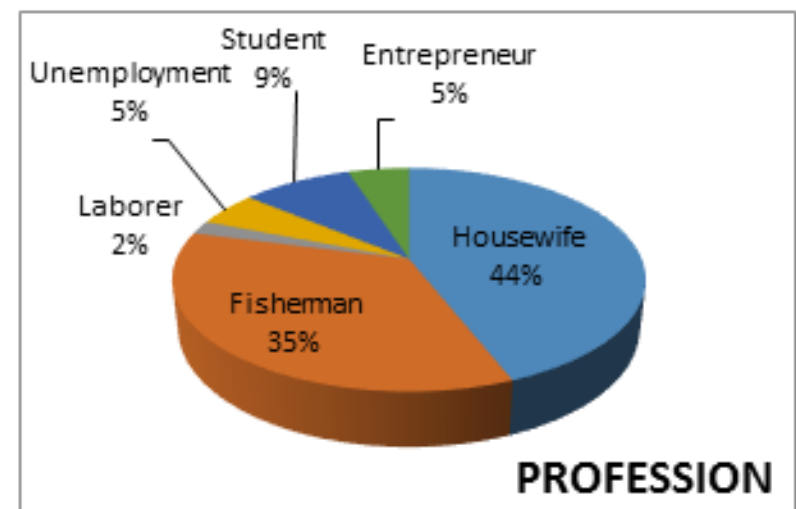

(a)

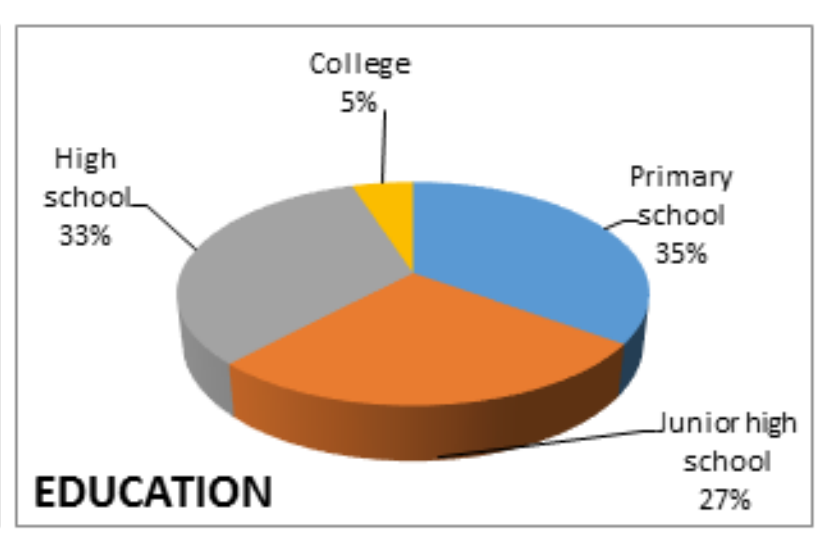

(b)

Figure 1. The social condition of Kuala Langsa society: (a) Respondents daily profession. (b)

Real-time education condition of the respondents.

While figure 1.b. Shows the educational level of the respondents consists of $35 \%$ of the respondents who graduated from elementary school, $27 \%$ graduated from junior high school, while $33 \%$ of high school graduated, and only $5 \%$ of the respondents could taste college education. The 
research data gained by counting the percentage index from questionnaire using Likert scale and converted into behavior using an indicator scale interpreted as the table showed as follow:

Table 1.

Respondents environmetal awareness

\begin{tabular}{lcc}
\hline \multicolumn{1}{c}{ Indicator } & Percentage Index & Interpretation \\
\hline Littering habits & $46.8 \%$ & Sometimes \\
Private toilet condition & $33 \%$ & Not Good \\
Product re-utilization & $36.2 \%$ & Rarely \\
$\begin{array}{l}\text { Water re-use for other } \\
\text { purpose }\end{array}$ & $36.6 \%$ & Rarely \\
Water collection for wash-use & $57.6 \%$ & Sometimes \\
\hline
\end{tabular}

The environmental awareness level of Kuala Langsa society is still low, according to the data above. It is shown by the littering habit at its proper place (sometimes) of Kuala Langsa society. For all these years, the local people throw garbage and defecate directly downward their houses, which will cause water pollution. This habit is also applied by most of the littoral villages of Indonesia. Even though those habits would be very affecting health and economic condition of the society, most of them working as a fisherman. The continuous result of that circumstances is that their catches decreased dramatically, and the low quality of health would also affect the productivity of society. The sanitation condition is also unwell because there is no septic tank available so that the contagious of diseases could be high risky

\section{Discussion}

The lack of awareness on preserving the environment cause negative effect to the environment. For most of Indonesian, unsecured waste-management is an acceptable act, without law consecuences. If this circumstances goes far, it will cause greater disaster such as flood. All garbage would flow and stuck the waterline which will trigger the water and environment pollution. If no straight act taken immediatelly, it would treaten the life of human being, animals, plants, and all the biodiversity. In other word we have to pay for the consecuences of environmental damage[12].

Environment problems and environmental awareness character of Gampong Kuala Langsa society formed by habit done by generations. These habits also being affected by their level of education and social condition around the neighborhood. So it would be very hard to change the bad habit to a better perspective. Therefore, it is necessary to build and form serious effort from 
all stakeholders to educate the people so that the clean and healthy littoral atmosphere could be gained to support the ecotourism sinergity and other local potential all at once to the health benefit of its society as well.

Through effective education, all wishes and hope of good deeds would come true. If reviewed from the educational aspect, educated people shows better awareness and understanding level to the environment which is positive for public participation to manage their environmental issues[1]. While less educated people shows the reverse.

According Masruroh[7] that environment could help a wise man to create and re-use of secondhand product into a highly valueable and environmentally friendly product. Therefore, formal and informal education plays a very important role to develop and improve human resources quality, specially upon the littoral community so that the people would have a highly environmental awareness character as Kuala Langsa society needed urgently.

\section{Conclusion}

The environmental awareness character of Kuala Langsa society is still low, proven by the surveyed respondent and questionnaire data processed through the Likert scale. To develop that character, certain educational pattern (informal) is required outside the school institution. Furthermore, various supporting facilities is needed so that the synergy to strengthen the ecotourism between the society and the environment could be reached, especially during the times of the Covid-19 pandemic.

\section{Acknowledgment}

Special thanks is expressed to Kemenristek/BRIN for providing grant funds in 2020 and for LPPM-PM Samudra University, who has contributed to this research in the field of administration.

\section{References}

[1] A. Lusi and Herlina, Community Participation in Environmental Management as an Effort to Create a Healthy and Comfortable Settlement (study in Notoprajan Ngampilan Yogyakarta village), Journal of Research Bapedda Yogyakarta, 1(6), 42-44 (2011).

[2] AB. Suwardi, \& IA. Zidni, \& Sofiyan. Komposisi Jenis Dan Cadangan Karbon Tersimpan Di Hutan Mangrove Kuala Langsa, Aceh (Composition of Types and Stored Carbon Stocks in the Mangrove Forest of Kuala Langsa, Aceh), SEMNAS BIOETI KE-4 \& KONGRES PTTI KE-12, (Paang, 2017).

[3] Badan Pusat Statistik Kota Langsa (Langsa City Central Bureau of Statistics) [BPS], Statistik Daerah Kota Langsa, (2015) 
[4] D. Purwanti, Pendidikan Karakter Peduli Lingkungan dan Implementasinya (Environmental Care Character Education and Its Implementation), DWIJACENDEKIA Jurnal Riset Pedagogik, 1(2), 14-20 (2017).

[5] M. Desfandi, Mewujudkan Masyarakat Berkarakter Peduli Lingkungan Melalui Program Adiwiyata (Creating a Community with Character Caring for the Environment through the Adiwiyata Program), Social Science Education Journal, 2 (1), 31-37 (2015).

[6] M. Muslich, Melaksanakan PTK itu Mudah (Implementing PTK is Easy). (Bumi Aksara, Jakarta, 2012), pp. 120-121

[7] Masruroh, Membentuk Karakter Peduli Lingkungan Dengan Pendidikan (Forming Environmental Care Character With Education), Jurnal Pendidikan Geografi (Journal of Geography Education), 18(2), 130-134 (2018).

[8] P. Andini and Safuridar, Peran Ekowisata dalam Pengembangan Pariwisata Berbasis Masyarakat (Studi Kasus: Hutan Mangrove Kuala Langsa) - (The Role of Ecotourism in Community Based Tourism Development (Case Study: Kuala Langsa Mangrove Forest)). Niagawan, 8( 2),113-120 (2019).

[9] SP. Febri, Analisis Kesadaran Masyarakat di Permukiman Nelayan Kuala Langsa Terhadap Dampak Pembuangan limbah Domestik Pada Perairan Pantai dan Laut (Analysis of Community Awareness in Kuala Langsa Fishing Settlements on the Impact of Domestic Waste Disposal in Coastal and Marine Waters), Jurnal Ilmiah Samudra Akuatika (Aquatic Ocean Scientific Journal), 1(1), 39-44 (2017)

[10] Sub Direktorat Statistik Lingkungan Hidup, Indikator Perilaku Peduli Lingkungan Hidup (Environmental Care Behavior Indicators) 2014, (Badan Pusat Statistik, Jakarta, 2015). pp. 101-109

[11] Suripto and L. Subayil, Pengaruh Tingkat Pendidikan, Pengangguran, Pertumbuhan Ekonomi dan Indeks Pembangunan Manusia Terhadap Kemiskinan di D.I.Yogyakarta Priode 20102017 (The Influence of Education Level, Unemployment, Economic Growth and Human Development Index on Poverty in D.I. Yogyakarta Period 2010-2017), GROWTH: Jurnal Ilmiah Ekonomi Pembangunan, 1(2), 127-143 (2020)

[12] YF. Pohan and RD. Supriharjo, Pengelolaan Sampah Perumahan Kawasan Perdesaan Berdasarkan Karakteristik Timbulan Sampah Di Kabupaten Gresik (Waste Management for Housing in Rural Areas Based on the Characteristics of Waste Generation in Gresik Regency), Jurnal Teknik Pomits, 2(1), 37-42 (2013) 